\title{
PEMANFAATAN APLIKASI SIANDINI SEBAGAI ALAT PEMANTAUAN DAN PENGENDALIAN INFLASI HARGA BAHAN KEBUTUHAN POKOK DAN BAHAN PENTING OLEH PEMERINTAH DAERAH KABUPATEN SUMBAWA
}

\author{
Erwin Mardinata ${ }^{1}$, Muhammad Saleh $^{2 *}$, Sherwin Ary Busman ${ }^{3 *}$ \\ 1Sekolah Pasca Sarja Universitas Teknologi Sumbawa \\ 2Sekolah Pasca Sarja Universitas Teknologi Sumbawa \\ ${ }^{3}$ Fakultas Ekomoni dan Bisnis Universitas Teknologi Sumbawa \\ *Corresponding Author email: muhammad.saleh@uts.ac.id, sherwin.ary.busman@uts.ac.id
}

\begin{abstract}
Abstrak
Diterima :

Penelitian ini membahas tentang pemanfaatan Inovasi Pelayanan Publik yang dilakukan Bulan Juni 2020 oleh Tim Pengendalian Inflasi Daerah (TPID) Kabupaten Sumbawa dalam upaya memudahkan proses pemantauan dan pengambilan kebijakan inflasi harga bahan kebutuhan pokok dan kebutuhan penting di kabupaten Sumbawa. Inovasi ini diberi nama SIANDINI (Sistem Informasi Peringatan Dini Inflasi) yang merupakan aplikasi di bidang tata kelola dan pelayana publik yang mengolah info harga realtime pada pasar induk

Diterbitkan: tradisional dan pasar modern di Kabupaten Sumbawa beserta analisis dan rekomendasi Bulan Juli 2020 bagi Pemerintah Daerah, Masyarakat, dan Swasta. Tujuan dari penelitian ini adalah untuk mengetahui hasil dan gambaran tentang pemanfaatan aplikasi SIANDINI dalam upaya pengambilan kebijakan yang tetap guna dan tepa sasaran. Penelitian ini menggunakan

Keyword : Bahan Pokok, Inflasi, Inovasi, Pelayanan Publik, SIANDINI jenis metode penelitian kualitatif - deskriptif dengan menggunakan teknik pengumpulan data wawancara, observasi dan dokumentasi. Hasil dari Penilitian apliasi SIANDINI berhasil menghasilkan capain yaitu memberikan kemudahan penggunaan aplikasi kepeda pengguna yaitu pemerintah dan masyarakat, sehingga kegunaan aplikasi SIANDINI membantu memberikan informasi harga kebutuhan pokok kepada masyarakat dan sebagai alat pendukung keputusan pengendalian inflasi oleh pemerintah.
\end{abstract}

\section{PENDAHULUAN}

Perkembangan teknologi informasi dewasa ini telah memberi dampak dan pengaruh besar dalam seluruh aspek kehidupan terutama dalam bidang pelayanan publik di pemerintahan. Pengembangan serta pemanfaatannya dalam bidang pelayanan publik di pemerintahan dapat menjadi inovasi yang bisa membantu kinerja, serta menjadi reformasi sistem pelayanan menjadi lebih baik, cepat dan tepat.

Teknologi informasi dengan berbagai kemampuan yang luar biasa seharusnya dimanfaatkan oleh pemerintah untuk membuat inovasi sebagai langkah awal mereformasi pelayanan agar melahirkan sistem layanan yang lebih baik, cepat dan mampu menghasilkan kebijakan-kebijakan yang tapat guna terutama dalam bidang perekonomian untuk pengendalian harga bahan kebutuhan pokok di masyarakat.

Bahan kebutuhan pokok merupakan bahan kebutuhan terpenting bagi masyarakat karena merupakan kebutuhan primer yang harus terpenuhi untuk menjamin keberlangsungan hidup. Jika kebutuhan primer tersebut tidak dapat terpenuhi, maka kebutuhan yang lainpun tidak bisa dipenuhi.
Ketersediaan stok kebutuhan pokok yang sedikit merupakan faktor terjadinya kenaikan harga sehingga mengakibatkan inflasi. Secara sederhana, meningkatnya harga-harga secara umum dan terus menerus disebut inflasi. Terjadinya inflasi secara terus menerus mengakibatkan kerugian bagi produsen dan menurutnya perekonomian masyarakat sehingga angkat kemiskinan meningkat.

Oleh karena itu, pemerintah yang direpresentasikan oleh Tim Pengendalian Inflasi Daerah (TPID) Kabupaten Sumbawa, membuat sebuah aplikasi berbasis web dan Android yang diberi nama SIANDINI (Sistem Informasi Peringatan Dini Inflasi Daerah). Aplikasi tersebut sebagai salah satu bentuk pemerintah dalam pemanfaatan kemajuan teknologi informasi di bidang tata kelola dan pelayanan publik yang mengelola informasi harga realtime pada pasar induk tradisional dan pasar modern di Kabupaten Sumbawa, sehingga harga bahan kebutuhan pokok dan kebutuhan penting lainnya, dapat mudah dipantau dan dianalisa dan dapat mencegah terjadinya inflasi oleh pemerintah. Selain itu, masyarakat juga mendapatkan keterbukaan informasi harga bahan kebutuhan pokok dan bahan 
penting dari pemerintah, beserta analisa kenaikan harga setiap saat.

\section{LANDASAN TEORI}

\section{Pelayanan Publik}

Menurut Pasalong (2010:128), pelayanan pada dasarnya didefinisikan sebagai aktifitas seseorang, sekelompok dan/atau organisasi baik secara langsung maupun tidak langsung untuk memenuhi kebutuhan. Jadi dapat dikatakan bahwa dalam pelayanan terdapat dua aspek yaitu seseorang/organisasi dan pemenuhan kebutuhan.

Sesuai dengan Undang-Undang Nomor 25 Tahun 2009 tentang Pelayanan Publik, Pelayanan publik adalah kegiatan atau rangkaian kegiatan dalam rangka pemenuhan kebutuhan pelayanan bagi setiap warga negara dan penduduk atas barang, jasa, dan/atau pelayanan administratif yang disediakan oleh penyelenggara pelayanan publik.

Pelayanan publik berdasarkan Surat Keputusan Menteri Pendayagunaan Aparatur Negara No: 63/KEP/M.PAN/7/2003 sebagai berikut: Pelayanan publik adalah segala kegiatan pelayanan yang dilaksanakan oleh penyelenggara pelayanan publik sebagai upaya pemenuhan kebutuhan penerima pelayanan maupun pelaksanaan ketentuan peraturan perundangundangan. Menteri Pendayagunaan Aparatur Negara dalam keputusan No.63 tahun 2003 tentang Pedoman Umum Penyelenggaraan Pelayanan Publik menyatakan bahwa "hakikat layanan publik adalah pemberian layanan prima kepada masyarakat yang merupakan perwujudan dari kewajiban aparatur pemerintah sebagai abdi masyarakat". Pernyataan ini menegaskan bahwa pemerintah melalui instansi-instansi penyedia layanan publik, mereka bertanggung jawab memberikan layanan prima kepada masyarakat. Dengan demikian pelayanan publik adalah pemenuhan keinginan dan kebutuhan masyarakat oleh penyelenggara negara.

\section{Inovasi Sektor Publik}

Sangkala (2013:27) Menyatakan Inovasi dalam manajemen sektor publik juga dapat didefenisikan sebagai pengembangan desain kebijakan baru dan standar operasi baru yang dihasilkan oleh organisasi yang ditujukan kepada masalah kebijakan publik sebuah inovasi dalam administrasi publik adalah efektivitas, kreativitas, dan jawaban unik terhadap masalah baru atau jawaban baru terhadap masalah lama. Sebuah inovasi tidaklah harus merupakan solusi yang sempurna atau berupa penyelesaian akhir, tetapi suatu solusi terbuka yang dapat di transformasi oleh mereka yang mengadopsi.

Bartos (Dalam Sangkala 2013) mendefinisikan inovasi yang tepat bagi sektor public yaitu "suatu perubahan dalam kebijakan atau praktek manajemen yang mengarah kepada perbaikan terbaru dalam level layanan atau kuantitas atau kualitas output oleh suatu organisasi”.

Menurut Yogi dalam LAN (2007), ditinjau secara lebih khusus, pengertian inovasi dalam pelayanan publik bisa diartikan sebagai prestasi dalam meraih, meningkatkan dan memperbaiki efektivitas, efisiensi dan akuntabilitas pelayanan publik yang dihasilkan oleh inisiatif pendekatan, metodologi dan atau alat baru dalam pelayanan masyarakat. Dengan pengertian ini, inovasi pelayanan publik tidak harus diartikan sebagai upaya menyimpang dari prosedur, melainkan sebagai upaya dalam mengisi menafsirkan dan menyesuaikan aturan mengikuti keadaan setempat. Sangkala (2013: 34) menyatakan bahwa Inovasi akan mengarahkan organisasi pemerintah pada perubahan organisasi di dalam lingkungan yang dinamis. Mengembangkan sebuah budaya inovasi akan mengarah kepada fleksibilitas organisasi dengan kepentingan tertentu dalam modernisasi program di sektor publik. Inovasi bukan mengenai teknologi itu sendiri tetapi lebih kepada bagaimana kita mengadaptasikan organisasi, pegawai, dan tempat pembelajaran untuk membangun masa depan yang lebih baik bagi pegawai. Saat ini dimana zaman perubahan teknologi terjadi, perubahannya tidak akan pernah berhenti, karena itu pemerintah harus memiliki keberanian dan ambisi untuk mendorong dan menerapkan perubahan.

\section{Kebijakan Pemerintah Daerah dalam upaya pengendalian Inflasi \\ Dalam upaya mengatasi permasalahan} inflasi harga bahan kebutuhan pokok dan kebutuhan penting, diperlukan sebuah kebijakan untuk mengaturnya. Kebijakan ini adalah kebijakan yang menyangkut perekonomian masyarakat banyak terutama masyarakat berpenghasilan kecil. Kebijakan adalah sebuah keputusan politis yang diambil oleh pemerintah sebagai bagian dari sikap pemerintah untuk memecahkan sebuah persoalan publik.

Pada prinsipnya sebuah kebijakan tidak terlepas dari keterlibatan seluruh element yang ada baik itu masyarakat sebagai bagian yang terikat dalam hasil putusan kebijakan sampai pada tahap pemerintah sebagai badan pembuat kebijakan tersebut. Kebijakan memiliki beragam definisi, yang masing-masing memiliki penekanan berbeda, hal ini tidak terlepas dari latar belakang seorang ilmuan tersebut. Namun demikian, satu hal yang perlu diingat dalam mendefinisikan kebijakan, adalah bahwa pendefinisian kebijakan tetap harus mempunyai pengertian mengenai apa yang sebenarnya dilakukan, ketimbang apa yang 
diusulkan dalam tindakan mengenai suatu persoalan tertentu. (Winarno, 2012:21).

Agustino dalam bukunya yang berjudul Dasar-Dasar Kebijakan Publik mengutip pendapat Carl Friedrich yang mengartikan kebijakan adalah adalah serangkaian tindakan/kegiatan yang diusulkan oleh seseorang, kelompok atau pemerintah dalam suatu lingkungan tertentu di mana terdapat hambatan-hambatan (kesulitan-kesulitan) dan kemungkinan-kemungkinan (kesempatankesempatan) di mana kebijakan tersebut diusulkan agar berguna dalam mengatasinya untuk mencapai tujuan yang dimaksud. (Friedrich dalam Agustino, 2012:7)

Berdasarkan penjelasan tentang konsep dari kebijikan, maka dapat disimpulkan kebijikan dalam penelitan ini dapat diartikan sebagai seperangkat keputusan yang diambil oleh pelakupelaku politik dalam rangka memilih tujuan dan bagaimana cara untuk mencapainya.

Kebijakan pemerintah pada prinsipnya dibuat atas dasar kebijakan yang bersifat luas. Mustopadidjaja dalam Tahir (2014:21) menjelaskan, bahwa istilah kebijakan lazim digunakan dalam kaitannya atau kegiatan pemerintah, serta perilaku negara pada umumnya dan kebijakan tersebut dituangkan dalam berbagai bentuk peraturan.

Salah satu kebijakan yang dikeluarkan oleh pemerintah untuk mengatasi permasalahan publik yang terjadi saat ini adalah kebijakan mengenai pencegahan terjadinya inflasi. Inflasi adalah kecenderungan naiknya harga umum barang dan jasa secara terus menerus akibat dari tidak ada keseimbangan arus barang dan arus uang. Suatu negara yang mengalami inflasi memiliki ciri - ciri sebagai berikut :

1. harga barang pada umumnya dalam kondisi naik terus menerus

2. Arus barang relatif sedikit

3. Arus uang yang beredar melebihi kebutuhan

4. Nilai uang (daya beli uang) menjadi turu

Pencegahan inflasi telah lama menjadi salah satu tujuan utama dari kebijaksanaan ekonomi makro pemerintahan dan bank sentral dinegara manapun. Hal ini disebabkan inflasi dianggap sebagai suatu yang tidak diinginkan dan inflasi memberi pengaruh yang tidak baik terhadap distribusi pendapatan (masyarakat berpendapat rendah akan menderita), kegiatan pinjam meminjam (pemberi pinjaman beruntung, peminjam merugi), spekulasi dan persaingan dalam perdagangan internasional.

Penelitian ini mengarah pada proses pemantauan harga bahan kebutuhan pokok dan kebutuhan penting sehingga dalam pemantauan, pemerintah dengan mudah dapat mengambil kebijakan-kebijakan yang tepat guna dan tetap sasaran. Proses pemantauan dilakukan dengan menggunakan inovasi SIANDINI. Inovasi SIANDINI adalah sebuah sistem informasi yang dibuat sebagai sistem pendukung keputusan atau decision support system untuk mengambil keputusan dan tindakan nyata yang tepat, cepat, dan efektif terhadap inflasi.

\section{Inflasi}

Bank Indonesia memberikan pengertian Inflasi yaitu meningkatnya harga-harga secara umum dan terus menerus. Kenaikan dari satu atau dua barang saja tidak dapat disebut inflasi kecuali bila kenaikan itu meluas (atau mengakibatkan kenaikan harga) pada barang lainnya. Kebalikan dari inflasi disebut deflasi (www.bi.go.id).

Inflasi merupakan salah satu permasalahan perekonomian yang sering terjadi di Indonesia. Inflasi diartikan sebagai kenaikan harga secara umum dan terus-menerus. Dapat dikatakan terjadi inflasi apabila kenaikan harga tersebut juga mempengaruhi kenaikan harga barangbarang lainnya. Pergerakan harga komoditas dapat dijadikan sebagai leading indicators inflasi. Beberapa alasannya adalah: (1) harga komoditas mampu merespon secara cepat shock yang terjadi dalam perekonomian secara umum seperti peningkatan permintaan (aggregate demand shock); (2) harga komoditas juga mampu merespon terhadap non-economic shocks, seperti: banjir, tanah longsor dan bencana alam lainnya yang menghambat jalur distribusi dari komoditas tersebut.

\section{MATODE PENELITIAN}

Penelitian ini dilakukan dan direncanakan berlangsung selama 1 bulan 20 hari. Lokasi penelitian dilakukan di Bagian Pekonomian Sekretariat Daerah Kabupaten Sumbawa.

Penelitian ini menggunakan jenis penelitian kualitatif dengan sifat penelitian deskriptif. Teknik pengumpulan data yang digunakan adalah wawancara mendalam, observasi dan dokumentasi.

Sumber data yang akan digunakan pada penelitian ini adalah data primer. Data primer adalah data yang yang diperoleh langsung oleh peneliti. Data primer pada penelitian ini berasal dari wawancara dan dokumentasi secara langsung yang dilakukan oleh peneliti. Data tersebut merupakan data yang bentuknya naratif, yaitu data yang berbentuk dalam kata-kata yang berasal dari informan. Wawancara mendalam dengan informan meliputi pihak pemerintah kabupaten Sumbawa yaitu Kepala Bagian Perekonomian Sekretariat Daerah Kabupaten Sumbawa, Kepala Subbagian Pengembangan Perekonomian Daerah dan ESDM, serta Kepala Bidang Perdagangan Dinas Koperasi, 
Perindustrian dan Perdagangan Kabupaten Sumbawa.

Studi ini berfokus pada praktik penggunaan dan pemanfaatan aplikasi SIANDINI sebagai alat pemantauan dan pengendalian inflasi, sehingga dapat diketahui apakah aplikasi berjalan dengan baik dan bisa menjadi salah satu alat pengambilan kebijakan pemerintah.

\section{HASIL DAN PEMBAHASAN}

Aplikasi SIANDINI adalah sebuah aplikasi bentuk inovasi di bidang tata kelola dan pelayanan publik. SIANDINI ini adalah sebuah sistem dan aplikasi yang mengolah info harga realtime pada pasar induk tradisional dan pasar modern di Kabupaten Sumbawa beserta analisis dan rekomendasi bagi Pemerintah Daerah, Masyarakat, dan Swasta.

Tujuan implementasi aplikasi SIANDINI adalah sebagai alat pemantauan dan pengendalian inflasi harga kebutuhan bahan pokok dan bahan penting oleh pemerintah kabupaten Sumbawa sehingga kebijakan yang dihasilkan lebih cepat, tepat dan tepat sasaran.

Pada penelitian ini, akan menjelaskan tentang beberapa aspek-aspek penggunaan dan pemanfaatan aplikasi SIANDINI yaitu aspek kemudahan penggunaan aplikasi SIANDINI dan Aspek kegunaan aplikasi SIANDINI.

\section{Aspek Kemudahan Penggunaan Aplikasi SIANDINI}

Kualitas dan kemanfaatan suatu aplikasi dapat diukur dengan melihat ketika pengelola dan pengguna mudah memahami serta mempelajari informasi yang ada didalam aplikasi. Menurut pengguna, aplikasi SIANDINI sangat mudah digunakan. Fitur-fitur yang disajikan tidak membingungkan pengguna dalam pengaksesannya. Seperti contoh beberapa fitur-fitur yang disajikan diaplikasinya seperti pada gambar dibawah ini.

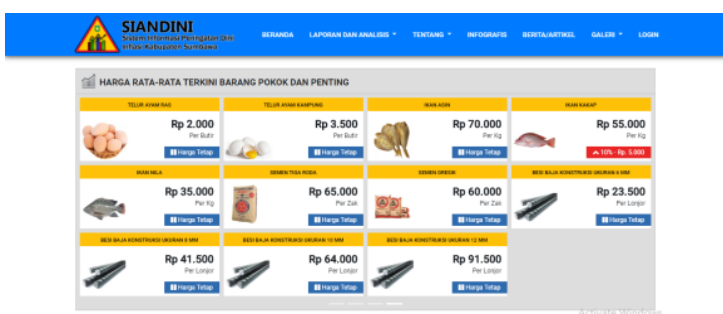

Gambar 1 Tampilan home aplikasi SIANDINI di Web

Gambar 1 menunjukkan bahwa pengguna dapat secara mudah mengakses informasi harga bahan pokok beserta persentase kenaikan dan penurunan harganya. Menurut pengguna aplikasi SIANDINI sangat mudah sekali diakses dan digunakan karena aplikasi SIANDINI ini tersedia di 2 platform yaitu berbasis web dan android sehingga pengguna secara bebas bisa mengakses data setiap saat dengan memanfaatkan smartphone dimiliki secara pribadi.

Pada aplikasi SIANDINI berbasis android, penggunaan aplikasi sangat mudah sekali digunakan. Kemudahan dalam penggunaan dapat membantu menemukan informasi yang dingin dilihat. Berikut tampilan aplikasi SIANDINI berbasis Android:

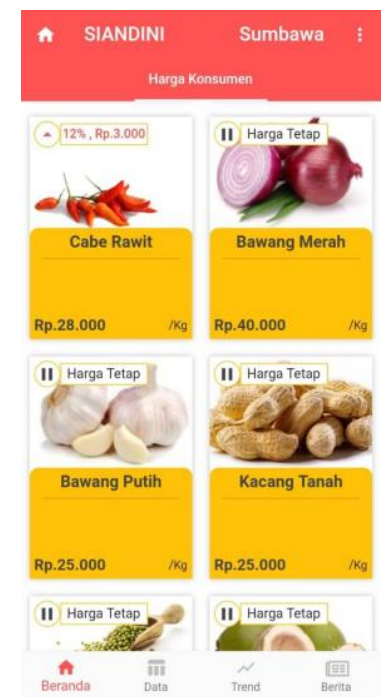

Gambar 2 tampilan home aplikasi SIANDINI berbasis Android

Kemudahan penggunaan aplikasi android dapat dilihat dari fitur-fitur yang tersedia pada aplikasi tersebut apakah fitur-fitur tersebut mudah digunakan atau tidak. Informan mejelaskan bahwa fitur-fitur atau menu yang tersedia pada aplikasi android ini mudah digunakan dan tidak sulit dalam penggunaaan dan pengoperasiannya. Kemudahan yang didapatkan dari penggunaan aplikasi SIANDINI tidak hanya dari kemudahan penggunanya tetapi tetapi juga kemudahan untuk menganalisa informasi atau outuput yang dihasilkan.

\section{Aspek kegunaan aplikasi SIANDINI}

Suatu aplikasi dikatakan berguna ketika dapat menjadikan pekerjaan menjadi lebih sangat mudah dan pleksibel. Setiap orang memiliki kebutuhan informasi yang berbeda-beda sesuai dengan profesi yang mereka jalani. Terutama pemerintah sebagai pelayan kepada masyarakat diharapkan bisa melayani kebutuhan informasi harga kebutuhan pokok. Menurun informan yang direpresentasikan oleh pemerintah kabupaten Sumbawa sangat membantu sekali dalam memberi 
layanan dan informasi harga bahan kebutuhan pokok ke masyarakat. Sebagai pengelolah aplikasi SIANDINI, pemerintah bertugas menginpukan data-data harga bahan kebutuhan pokok ke dalam aplikasi yang diambil dari hasil survey ke pasar induk yang ada di kabupaten Sumbawa. Data tersebut secara otomatis dikelola oleh aplikasi yang akan menghasilkan informasi atau output yang digunakan sebagai dasar penentuan kebijakan yang terjadi pada harga bahan kebutuhan pokok tersebut. Dibawah ini adalah gambar output dari data yang diinputkan kedalam aplikasi SIANDINI:

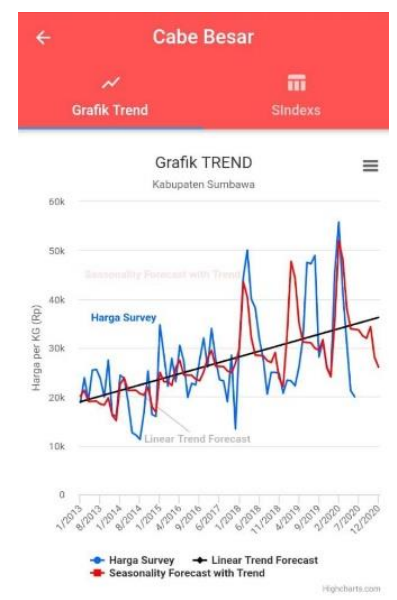

Gambar 3 Tampilan grafik trend dan sindex aplikasi SIANDINI

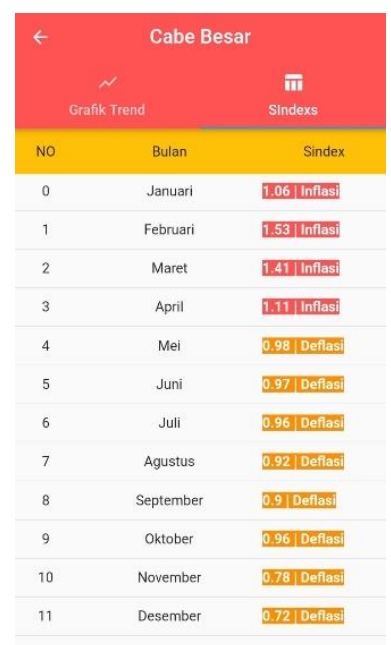

Gambar 4 Tampilan sindex aplikasi SIANDINI

Pada gambar 3 dan gambar 4 diatas adalah hasil dari data harga salah satu bahan kebutuhan pokok yaitu cabe besar yang diinpukan kedalam aplikasi setiap saatnya. Data yang dihasilkan tersebut berupa menghasilkan grafik harga survey, linear trend forcast dan sesionality forecast with trend dan sindex. Dari ke 3 grafik dan sindex harga, informan yaitu pemerintah bisa mengetahui harga peramalan di bulan yang akan datang. Sehingga pemerintah dapat melakukan antisipasi kenaikan harga atau terjadi inflasi harga.

Dari keterangan diatas, dapat diketahui bahwa aplikasi SIANDINI meningkatkan kinerja pekerjaan pemerintah dalam pelayanan kepada masyarakat. Hal ini sesuai dengan prinsip diciptakannya teknologi bawah teknologi merupakan suatu bentuk proses yang meningkatkan nilai tambah.

\section{PENUTUP}

\section{Kesimpulan}

Berdasarkan hasil pembahasan dari penelitian yang telah diuraikan oleh penulis, maka Pemanfaatan Inovasi SIANDINI dalam Pemantauan dan Pengambilan Kebijakan Inflasi Harga Bahan Kebutuhan Pokok dan Bahan Penting oleh Pemerintah Daerah Kabupaten Sumbawa dapat diambil kesimpulan yaitu Pemanfaatan Aplikasi SIANDINI sudah memberikan kemudahan kepada para pengguna dalam hal ini pemerintah dan masyarakat. Dimana, aplikasi ini mampu dikendalikan dengan mudah dan cepat. Fitur-fitur yang disajikan juga sangat mudah diakses dimana dan kapan saja karena tersedia dalam basis web dan basis android. Sehingga Pemanfaatan Aplikasi SIANDINI sudah mampu membantu meningkatkan kualitas pelayanan pemerintah kepada masyarakat yang memberikan informasi harga-harga barang kebutuhan pokok yang up to date.

\section{REFERENSI}

Pasolong, Harbani. 2010. Teori Administrasi Publik, Alfabeta, Bandung

Undang-Undang Republik Indonesia Nomor 25 Tahun 2009 Tentang Pelayanan Publik

Keputusan Menteri Pendayagunaan Aparatur Negara Nomor: 63/KEP/M.PAN/7/2003 tentang Pedoman Umum Penyelenggaraan Pelayanan Publik.

Sangkala. 2013. Innovative Governance :Konsep dan Aplikasi. Surabaya : Capiya.

Winarno, Budi. 2012. Kebijakan Publik. Jakarta : CAPS

Agustino, Leo. 2012. Dasar-Dasar Kebijakan Publik. Alfabeta: Bandung

Sangkala. 2013. Innovative Governance :Konsep dan Aplikasi. Surabaya : Capiya. 
SPECIAL ISSUE

JURNAL TAMBORA VOL. 4 NO. 2A JULI 2020

http://jurnal.uts.ac.id

Science and Technology

Machfoedz, Mahmud. (2010), "Komunikasi Pemasaran Modern", Cetakan Pertama, Cakra Ilmu, Yogyakarta. 